\title{
EDITORIAL. Implant Treatment Method's Evolution: Pure Science Guided or Wild Darwin's Evolution?
}

\section{Gintaras Juodzbalys ${ }^{1}$}

${ }^{1}$ Department of Maxillofacial Surgery, Lithuanian University of Health Sciences, Kaunas, Lithuania.

\section{Corresponding Author:}

Gintaras Juodzbalys

Vainiku 12, LT-46383, Kaunas

Lithuania

Phone: +370 37297055

Fax: +37037323153

E-mail: gintaras@stilusoptimus.1t

Accepted for publication: 19 December 2017

To cite this article:

Juodzbalys G.

EDITORIAL. Implant Treatment Method's Evolution: Pure Science Guided or Wild Darwin's Evolution?

J Oral Maxillofac Res 2017;8(4):e1

URL: $\underline{\text { http://www.ejomr.org/JOMR/archives/2017/4/e1/v8n4e1.pdf }}$

doi: $10.5037 /$ jomr.2017.8401 
Replacing missing teeth with titanium dental implants has become a routine procedure. High survival rates, ranging above $95 \%$ over a period of 10 years has been reported $[\underline{1}, \underline{2}]$. However, the survival rate does not take into account the presence of biological complications. Today, the number of patients presenting with peri-implant diseases are increasingly growing [3]. Peri-implant diseases affecting the surrounding structures of endosseous dental implants, include peri-implant mucositis and peri-implantitis. The $11^{\text {th }}$ European Workshop on Periodontology consensus conference concluded that mean prevalence of peri-implant mucositis and peri-implantitis is $43 \%$ and $22 \%$ respectively [4]. According to some authors, the number of peri-implantitis is alarmingly increasing till $43.3 \%$ [ $\underline{5}$.

In early 1980s, while talking about the concept of osseointegration, Brånemark distinguished two main reasons of implant loss: poor surgical technique and occlusal overload. Thereafter, the scientists and clinicians highlighted a number of new aetiological factors in peri-implantitis development. Nowadays, we are discussing about multi-factorial aetiology of peri-implantitis i.e. different factors at implant (shape, surface), patient (local and systemic factors), and clinician (competence, new protocols) level. Furthermore, the diagnosis and consequently the evaluation of prevalence of peri-implantitis are too complicated, because there are no unified diagnostic criteria. The natural question then arises: what happened with Brånemark's osseointegration phenomenon in modern era and why we cannot stop the development of peri-implantitis?

First of all, we should recognize that standard Brånemark "biocompatibility"-oriented protocol seeking for qualitative osseointegration, has been changed dramatically. Nowadays, clinicians are using new protocols to accelerate the treatment procedure - immediate implant placement, immediate loading, or seeking for better aesthetic result - soft tissue grafting, or expanding treatment indications - using different augmentation techniques of the alveolar process. Even a recommended minimal number of dental implants for edentulous jaws rehabilitation were reduced. For example, "all on four" method is recommending only 4 implants in edentulous maxillae. Changes occurred in all fields of implant treatment, including general indications and planning, surgical and prosthetic protocol, timing, and implant material and design. It is difficult to draw the particular connection between the complications, such as peri-implantitis and innovations, related with method evolution, but one is clear - the new protocols are increasing risk of complications and susceptibility for peri-impantitis development. Furthermore, the number of clinicians performing implant surgery is increasing continuously. Even the dental implant companies are stimulating those processes and young specialists are accepting the challenging cases with enthusiasm and it leads to the increased number of complications.

Some of the authors are highlighting significance of the inflammation due to bacterial load i.e. biofilm and opportunistic infection [6]. Opportunistic microorganisms such as enteric rods and Staphylococcus aureus are appearing in oral cavity due to a change in the environment, which allows the normally present pathogens to proliferate. Interestingly, the bacteria in a biofilm are extremely resistant to antibiotics. All the methods of plaque control should be employed first, because it is impossible to increase the dosage of antibiotics capable to destroy the biofilm. Maintaining of the good periodontal health and elimination of the reservoirs of pathogens will help to prevent development of peri-implantitis. However, it is wrong to believe that the dramatic changes in our patients' microbiota occurred during the last decade. We should accept the fact that the expanded diagnostic possibilities just gave us better understanding about the biological processes presenting in oral cavity.

In contrast, huge changes occurred in shapes and materials of the dental implants. Biomedical research is focused on implant geometry and the osteoinductive potential of implant surfaces. In 2009, Junker with co-authors [7] reported that 1,300 different implant systems exist, varying in shape, dimension, bulk and surface material, thread design, implant-abutment connection, surface topography, surface chemistry, wettability, and surface modification. In 2008, Jokstad [8] mentioned higher standard principles of the research quality recommended by Brånemark's team. The author wrote: "In fact, this level of research quality is what we would expect should be conducted to support the introduction of new implants or surgical interventions, which unfortunately is not the situation today". Furthermore, the author raised few very interesting questions:

- How many implant brands do we really need?

- Are the regulatory agencies doing their job?

- How reliable are experimental data for predicting clinical outcomes?

- Does the surface topography really make a difference?

- What are the relevant morphological differences between implants?

Nowadays, those questions by Jokstad [ $\underline{8}]$ are probably still alive and relevant to us. 
Simion [9] was even more radical and invited colleagues to come back to the traditional Brånemark concept of an implant: "I believe the most respected researchers and clinicians - rather than the companies - will take collective responsibility for leading the way back to the traditional Brånemark concept of an implant with a machined surface, loaded only after a sufficient period of time for the bone to adapt to a foreign body, which rather than being called an implant is known as a 'fixture'. This will restore confidence and credibility to our work, and more importantly provide a long-term safe treatment option for our patients".

In my opinion, we should not turn back, because certainly we are witnessing the dental implant method evolution. However, I would like to take a part in pure science guided evolution, but not Darwin's wild evolution, where the strongest or fastest will survive. I do not like to check on my patients, which one implant or modification is better, because remember the Hippocratic Oath which begins with the words "First, do no harm". Peri-implantitis is "man's made" disease and this is the reason why we should stop for a moment and try to think about the equilibrium between the pure research and the commercialisation; expanded indications, speed up protocols and loss of confidence either in dental implant method and us. We should feel more responsibility and be more realistic in judgement of the dental implant method evolution, or our patients will judge us.

\title{
REFERENCES
}

1. Lang NP, Berglundh T, Heitz-Mayfield LJ, Pjetursson BE, Salvi GE, Sanz M. Consensus statements and recommended clinical procedures regarding implant survival and complications. Int J Oral Maxillofac Implants. 2004;19 Suppl:150-4. [Medline: 15635955$]$

2. Pjetursson BE, Tan K, Lang NP, Brägger U, Egger M, Zwahlen M. A systematic review of the survival and complication rates of fixed partial dentures (FPDs) after an observation period of at least 5 years. Clin Oral Implants Res. 2004 Dec;15(6):667-76. [Medline: 15533127] [doi: 10.1111/j.1600-0501.2004.01120.x]

3. Koldsland OC, Scheie AA, Aass AM. Prevalence of peri-implantitis related to severity of the disease with different degrees of bone loss. J Periodontol. 2010 Feb;81(2):231-8. [Medline: 20151801] [doi: 10.1902/jop.2009.090269]

4. Derks J, Tomasi C. Peri-implant health and disease. A systematic review of current epidemiology. J Clin Periodontol. 2015 Apr;42 Suppl 16:S158-71. [Medline: 25495683] [doi: 10.1111/jcpe.12334]

5. Zitzmann NU, Berglundh T. Definition and prevalence of peri-implant diseases. J Clin Periodontol. 2008 Sep;35 (8 Suppl):286-91. [Medline: 18724856] [doi: 10.1111/j.1600-051X.2008.01274.x]

6. Lafaurie GI, Sabogal MA, Castillo DM, Rincón MV, Gómez LA, Lesmes YA, Chambrone L. Microbiome and Microbial Biofilm Profiles of Peri-Implantitis: A Systematic Review. J Periodontol. 2017 Oct;88(10):1066-1089. [Medline: 28625077] [doi: 10.1902/jop.2017.170123]

7. Junker R, Dimakis A, Thoneick M, Jansen JA. Effects of implant surface coatings and composition on bone integration: a systematic review. Clin Oral Implants Res. 2009 Sep;20 Suppl 4:185-206. [Medline: 19663965] [doi: 10.1111/j.1600-0501.2009.01777.x]

8. Jokstad A. Oral implants--the future. Aust Dent J. 2008 Jun;53 Suppl 1:S89-93. [Medline: 18498590] [doi: 10.1111/j.1834-7819.2008.00046.x]

9. Simion M. Osseointegration: where we started from and where we are going (page 2). 2014 May. [URL: https://www.eao.org]

\author{
To cite this article: \\ Juodzbalys G. \\ J Oral Maxillofac Res 2017;8(4):e1 \\ URL: http://www.ejomr.org/JOMR/archives/2017/4/e1/v8n4e1.pdf \\ doi: $\underline{10.5037 / j o m r .2017 .8401}$
}

EDITORIAL. Implant Treatment Method's Evolution: Pure Science Guided or Wild Darwin's Evolution? 
Copyright (C) Juodzbalys G. Published in the JOURNAL OF ORAL \& MAXILLOFACIAL RESEARCH (http://www.ejomr. org), 31 December 2017.

This is an open-access article, first published in the JOURNAL OF ORAL \& MAXILLOFACIAL RESEARCH, distributed under the terms of the Creative Commons Attribution-Noncommercial-No Derivative Works 3.0 Unported License, which permits unrestricted non-commercial use, distribution, and reproduction in any medium, provided the original work and is properly cited. The copyright, license information and link to the original publication on (http://www.ejomr.org) must be included. 